\title{
Urology in forensic medicine registries in Ottoman court registry books
}

\section{Ekrem Güner (1)}

Cite this article as: Güner E. Urology in forensic medicine registries in Ottoman court registry books. Turk J Urol 2020; 46(1): 80-6.

ORCID IDs of the authors: E.G. $0000-0002-4770-7535$.

Department of Urology, University of Health Sciences, Bakırköy Dr. Sadi Konuk Training and Research Hospital, İstanbul, Turkey

\section{Submitted:}

07.04.2019

Accepted:

04.11.2019

Available Online Date: 29.11.2019

\section{Corresponding Author:}

Ekrem Güner

E-mail:

ekremguner@yahoo.com

(C) Copyright 2020 by Turkish

Association of Urology

Available online at

www.turkishjournalofurology.com

\begin{abstract}
Objective: Efforts to determine crimes and culprits were carried out in the Ottoman Empire as in every society. Until the second half of the $19^{\text {th }}$ century, when forensic medicine was institutionalized, the records belonging to these applications were held by the institution of "Qadi" in court registry books. In this study, based on these Shariah court records, we aimed to reveal Ottoman period forensic science procedures and urology's place in them.
\end{abstract}

Material and methods: Literature searches were made with certain keywords in Ottoman medical sources. Ottoman archive documents and relevant literature were examined in terms of forensic practices and urology, especially in Shariah court records belonging to several cities.

Results: Signing Ottoman consent documents before medical interventions, the judgment of physicians due to fraud and mistakes, the consultation of physicians in injuries, infectious diseases, and on-site exploration of deaths were identified as the main forensic medicine applications. Extensive information about urologic diseases and forensic urology of the period in the consent documents was uncovered.

Conclusion: Shariah court records provided information, through consent documents, about forensic medicine procedures, urogenital diseases, and urologic forensic cases of the period. Informed consent documents, which were introduced in Europe in the 19th century, were used in the Ottoman Empire since the 15 th century, showing the Ottomans' medical ethics in terms of physician and patient rights.

Keywords: Court records; forensic medicine; history of urology; informed consent; Ottoman medicine.

\section{Introduction}

The Tiphane (medical school), was established in the $19^{\text {th }}$ century because medical education in madrasahs was considered inadequate. Ottoman administrators wanted to bring medical developments in Europe to the country. Before then, physicians were trained in the masterapprentice method in madrasahs or special clinics, called "Dukkan," under master physicians with diplomas. ${ }^{[1]}$ After Sultan Mahmud II (1785-1839) removed the guild of janissaries, the need for adequate numbers of physicians and surgeons for the new army (Asâkir-i Mansûre-i Muhammediye), established in 1826, supported these renewal efforts. For this purpose, on March 14, 1827, "Tibhane-i Amire" and, five years later, "Cerrahhane-i Amire" were established. These two medical schools were combined in 1836 and named "Mektebi Tibbiye." The school moved to Galatasaray in 1839 and was named "Mekteb-i Tibbiye-i Adliye-i Şâhâne." To develop Turkish medicine, Dr. Charles Ambroise Bernard (18081844) was invited from Vienna to provide medical education at this school with the title of "muallim-i evvel" (Senior teacher).

After medical schools were established and modern medicine began to evolve as European physicians came to teach in these schools, important developments in forensic medicine began to occur. Besides, "securing life, goods, honor, and pudicity" of people in the rescript of Gulhane (Tanzimât Fermânı), which was announced by Sultan Abdülmecid (1839-1861) on November 3, 1839, initiated the Ottoman Empire's first democratic constitutional process. It also played a major role in the birth of 
forensic medicine in the Ottoman Empire. ${ }^{[2]}$ Dr. Bernard taught his first forensic medicine classes in 1841 with the name "Tibb-1 Kanuni."

In the same year, Sultan Abdulmecit II allowed cadaver dissection and autopsy practices on the corpses of Christians (autopsies on Muslims were considered sins). Dr. Bernard performed his first autopsy in $1843{ }^{[3,4]}$ After his death, the forensic medicine department was established in 1846 in medical school, and forensic medicine lessons were taught by physician Servicen Efendi. ${ }^{[5]}$

With Sultan Abdulmecit's 1857 edict, the first step toward a forensic medicine organization was laid in the Ottoman Empire with the establishment of the "Medical and Judicial commission," linked to the "Meclis-i Umur-1 Tibbiye." The law of criminal proceedings (Usul-1 Muhakemat-1 Cezaiye Kanun-1), which took effect for the first time in 1879, determined the rules of forensic autopsies, and identified official expertise for the first time. ${ }^{[4]}$

However, it was not easy to reach this stage in the Ottoman Empire. For example, Şeyhülislâm Mevlâna Alâaddin-i Aliyül Arabi, who was a contemporary of Sultan Beyazit II (14471512), objected to conducting autopsies in 1494 . He issued a fatwa announcing that those who engaged in this work would be blasphemers, so none were performed for about 350 years until $1841 .^{[6]}$

The untouchableness of human body, health and life from the individual rights in the Islamic law is based on the Prophet Muhammad's words: "Your lives, your possessions, and your blood are untouchable and protected from all kinds of rape".$^{[7,8]}$ For this reason, efforts to determine crimes, offenders, and victims were carried out in the Ottoman Empire in various ways. A judicial organizational structure was established based on the institution of the "Qadi" since the empire's earliest days. These courts, where the single Qadi was served, were named as the Shariah court. ${ }^{[9,10]}$ Although there are written sources that shed light on forensic practices in late periods of the empire, there are insufficient written sources from earlier periods. In these periods, the information about the practice of medical and forensic medicine was in the legal texts held by the institution of the "Qadi."[11] These texts, called the Ottoman Shariah court records ("Şer'iyye Sicilleri" or "sicillât-1 şer'iyye"), were also named court registry books, judicial records or Qadi registry books. ${ }^{[12,13]}$

This article aims to reveal the information and procedures related to Ottoman period forensic medicine and urology based on Ottoman Qadi registry books. Forensic medicine information and procedures pertaining to urology, obtained from translated texts, are revealed below under the titles of the Ottoman consent documents and physician fees, physicians' malpractice and fake physicians without diplomas, forensic expertise, and forensic exploration.

\section{Material and methods}

Literature searches were made in the Ottoman archives and in translated Ottoman medical resources from libraries, by using keywords such as "bevliye," "bevl," kulvet (kilye, kulvi, kulvâtün), mesâne, burostât (iltihâbi'l burostât), hasât-ı bevliyye (husva, husvâtu'l-kulye, husvâtu'l-mesâne), karha-i habis, zeker, husye which mean urology, urine, kidney, bladder, prostate, stone, syphilis, penis, and testis, respectively. In addition, literature searches were conducted using the words "Tibb-i Kanuni," which means forensic medicine, and "feth-i meyit and teşrih," which means autopsy. Ottoman archive documents, especially court records from various provinces, and literature from medical history museums and library resources were examined, in terms of forensic medicine practices and urology of the period, and were interpreted considering the times. For this purpose, the earliest court records in Istanbul, Denizli, Kayseri, Konya, Manisa, Amasya, and Antep provinces, and especially in Bursa province, which have been translated into Turkish, were the main literature sources that were searched.

\section{Ottoman consent documents and physician fees}

The present-day equivalent to the informed consent form, which was shaped by the $19^{\text {th }}$ century in the West and started to find a response in the law with the word "informed consent," refers to explaining the treatment method, purpose, scope, risks, and alternative treatment methods to patients. The patient would then sign the form, of his/her own free will, together with a physician. ${ }^{[14]}$ The history of Turkish medicine indicates that this agreement, which is realized between patient and physician, is done under the term consent documents ("riza senedi") in the Ottoman period. In accordance with this convention, the patient declares that he/she hires a physician or surgeon for his/her treatment or surgery in exchange for the price they negotiate in front of the witnesses. In the presence of Qadi and witnesses, patients were asked to sign and affirm that, if they were injured or died at the end of surgery or treatment, they or their relatives would not file a claim for compensation. ${ }^{[15]}$

Almost all the consent documents examined included the name of patient, physician, and disease, while many of them included the fees to be paid to physicians for treatment or surgery. ${ }^{[16]} \mathrm{An}$ example of this situation was observed in the Bursa court records of 1538 A.D. According to this document, a patient named Dimitri, son of Nikola from the district of Balikpazari, agreed that the surgeon Seyyid Ali, son of Bereket, would remove a bladder stone. In the presence of witnesses in the Shariah court, Dimitri accepted that if he was injured or died during the procedure, the physician would not be prosecuted or compensated (Figure 1). 


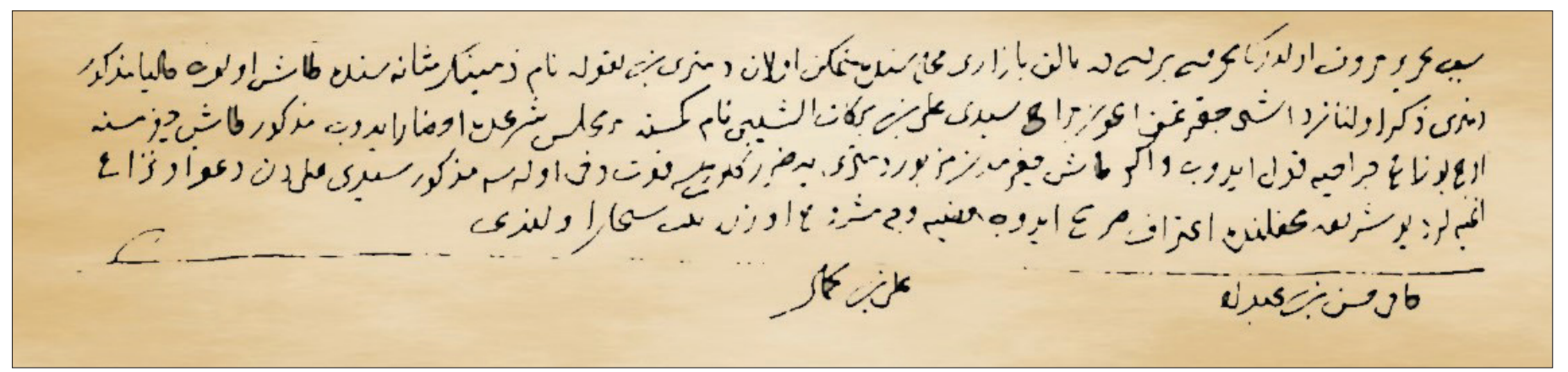

Figure 1. The Ottoman consent document related to bladder stone surgery, Bursa Shariah records, Bursa

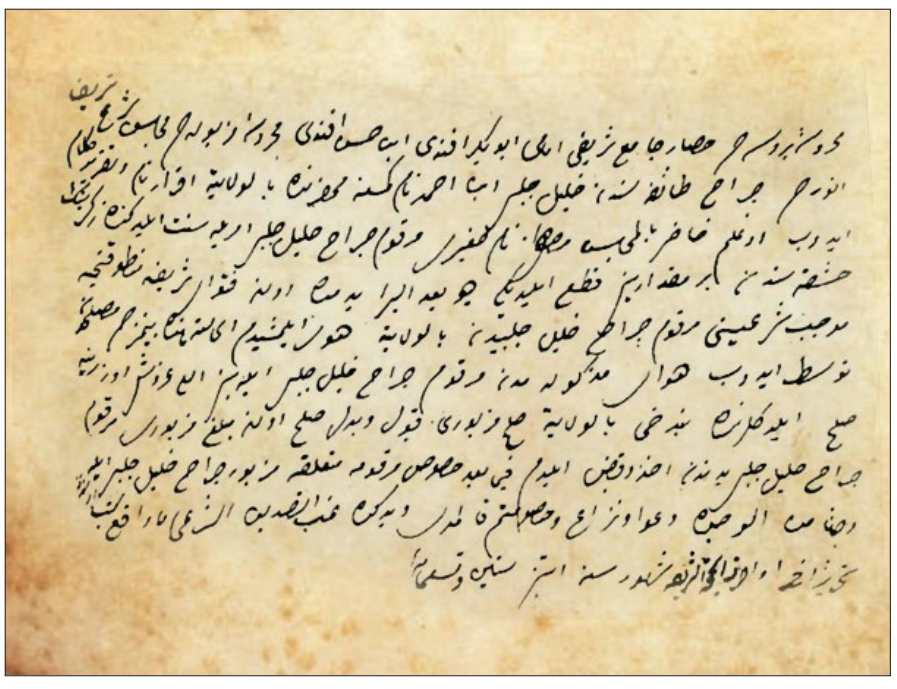

Figure 2. Document on the case where the glans penis was injured in the circumcision process, Bursa Shariah records, Bursa

Another entry in the Bursa Shariah records revealed the monthly salary of a physician who did not have a special clinic. It is understood from this record that Muhyiddin Efendi, who died in 1525 , received a salary of 8 akce daily ( 240 akce for a month) in "dar al-shifa" as a physician. ${ }^{[11]}$ In the example of consent document above, dated 1538, three hundred akce paid for bladder stone surgery exceeded the physician's monthly salary.

Physicians' malpractice and fake physicians without diplomas

Professional physicians were considered craftsmen during the Ottoman period, in the class of artisan. Like other artisan groups, they had no social security, occupational insurance, or privileges. Patients were able to go to Qadi and complain about medical treatment and interventions that the physician had done. For this reason, physicians asked for signed consent documents before beginning treatments to avoid being subjected to lawsuits and avoid coming into the Qadi's presence. After patients signed this consent document in the presence of the Qadi and witnesses, consenting to the treatment or the intervention, and absolving the physicians from responsibility for problems arising from the treatments, then the treatment would begin. In this way, the physician would be exempt from the expenses of many problems that could occur during the treatment period. In addition, despite the receipt of consent document, records of filed legal cases were found in the Qadi records of the period, and the situation is quite similar to the present day. ${ }^{[17]}$

According to the court records, people sometimes complained of their dissatisfaction with the physician's mistakes or treatment, similar to today. ${ }^{[1,17]}$ In a Bursa court record from 1554 A.D., the surgeon Halil Celebi, the son of Ahmet, circumcised Mustafa, the youngest son of Ebubekir Efendi, who was the Hisar Mosque imam. The imam was the plaintiff, claiming that the surgeon had cut a small amount from the head of his son's penis (Figure 2) ${ }^{[11]}$

Also similar to today, inexperienced physicians also existed in that period. In a Bursa court record dated 1845, Saadettin of Bursa, a surgeon in Istanbul, had a malpractize complaint lodged against him after a bad surgery. He was informed by the chief physician of the palace that he had no knowledge of the medicine and that he should never have been a physician; thereafter, he was sent into exile to Bursa. ${ }^{[18,19]}$

It was observed that the diplomas of all medical craftsmen (physician, pharmacist, midwife, nurse) were controlled countrywide by the "Meclis-i Umur-1 Tibbiye-i Mülkiye" which was established in the Ottoman Empire in 1840. ${ }^{[2]}$ Nevertheless, one case of a fake physician was recorded in an incident in Denizli province. According to this, Perikli, a Greek citizen, practiced medicine in Denizli for three years even though he had no diploma. Most of the people he treated were injured, and the survivors became crippled or sick. Therefore, Meclis-i Vâlâ-yı Ahkâm-1 Adliye responded to petition, dated 1866, which demanded the physician's removal from Denizli, stating that those who did not have a diploma or a medical leave certificate issued by Mekteb-i Tıbbiye-i Şâhâne were forbidden from practicing medicine, and the policy should take effect quickly (Figure 3). ${ }^{[7,8]}$ 


\section{Forensic expertise}

In modern law, courts request forensic examinations and reports from physicians in case of injuries or accidents investigated by the prosecution office; these forensic reports also orient the case significantly. Similarly, in the Ottoman legal system, the institution of Qadi applied to the examination and expertise of physicians in forensic injuries and infectious diseases. A woman named Kamer, a Kara Şeyh neighborhood resident, was injured, which was recorded in Bursa court documents. Her neighbors reported it to the judicial authority; then Mevlâna Ibrahim was appointed to examine the situation and woman. In his examination, the physician reported that the injury occurred when one wall of the woman's home collapsed. The lady said that "If I die due to this injury, the people of the neighborhood have no responsibility." (Figure 4) ${ }^{[18]}$ The Qadi asked a surgeon to examine a person who was beaten, according to a Kayseri record of 1744 A.D. ${ }^{[16]}$ In addition to these, in Bursa record dated 1537 A.D., it was understood that a purchased Hungarian female slave named Peyman had syphilis (karha-i habis); the claim that the woman contracted the disease before the purchase date was confirmed by the physician's report requested by the Qadi, after which the sale was canceled. ${ }^{[11]} \mathrm{A}$ similar situation in Bursa in 1587 was observed in the petition of Raziye, the daughter of Kasim, who claimed to be suffering from syphilis from her new husband; the Qadi asked for a physician's opinion, and consequently, he decided the couple's divorce after the claim was proved. Despite the fact that the right to divorce belonged to the man in the Ottoman law, women also had the right to divorce in case of a serious illness or erectile dysfunction. ${ }^{[18,19]}$

\section{Forensic exploration}

In today's death cases, physicians perform a death examination to determine the cause of death and how it occurred. In this examination, a death certificate is prepared for cases in which the cause of death is determined. An autopsy is requested for further investigation in cases that are suspicious or unexpected, for which a cause is unknown, or that carry a judicial character. ${ }^{[20]}$ In addition, the investigation of the crime scene, called forensic exploration, is carried out under the presiding court judge to understand how the incident occurred, the criminal evidence of the suspect, and the damage and loss which occurred. ${ }^{[16,21,22]}$

During the research, it was found that the information about the forensic practices in the cases of murder and death in the early Ottoman period was insufficient. Since 1453, when the state passed from seigniory to empire, the judicial officer's decision and conviction were accepted as valid in death cases and the burial processes. In later periods, it was understood from the Qadi records that a corpse was often examined by a delegation with a physician in cases of deliberate injury, accident, suicide, or death due to murder. ${ }^{[6,18]}$ After the victim or the victim's relatives submitted a forensic exploration application, those who came to the court were questioned in court. Those who were unable to come were questioned where they lived. The victim's injuries were also investigated, and a judicial report was prepared..$^{[23]}$ The exploration was conducted by Qadi or by trusted people, including a qualified physician, who were appointed by Qadi. ${ }^{[24]}$

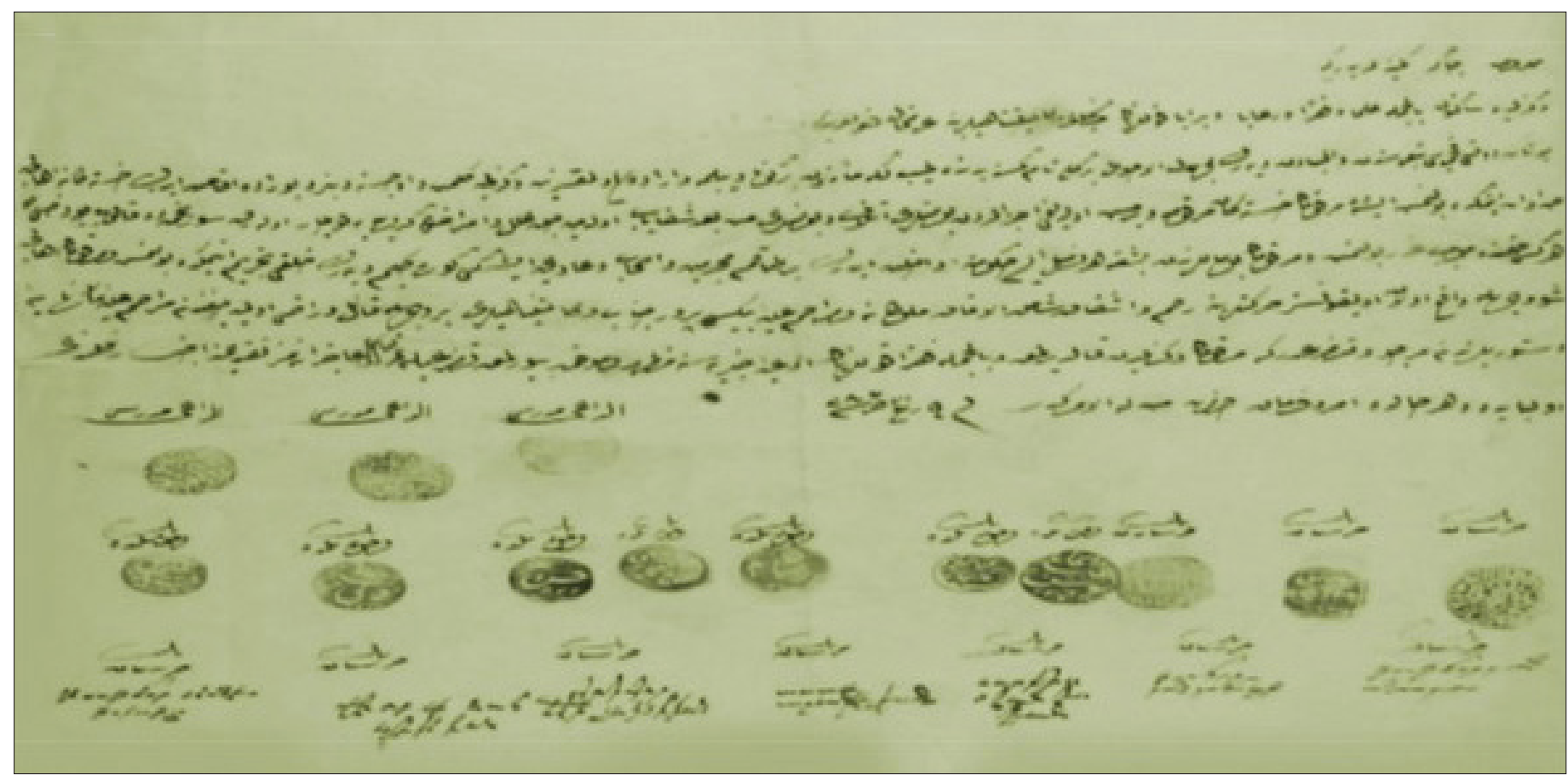

Figure 3. The petition of Muslim and non-Muslim local society who complained about the physician Perikli who had not a diploma, Denizli Shariah records, Denizli 
An example of the forensic exploration application was found in the court records of Bursa in 1552 A.D. According to this, Şahban Hatun, the daughter of Ramadan, claimed that Ali, her son, were killed by Celal, the son's master, by battering. On this, the physician Mustafa, son of Ahmed, and surgeon Pir Ahmet Celebi, son of Hayreddin, were commissioned by the court to investigate the death. They did not find any beating signs on the corpse (Figure 5). ${ }^{[18,19]}$

In Islam, the creation and sacred nature of the human body by God created the most significant obstacle to autopsy. For this reason, only an external examination of the deceased person was made to try to determine the cause of death. Exploration reports included information such as the cause of the incident, the cause

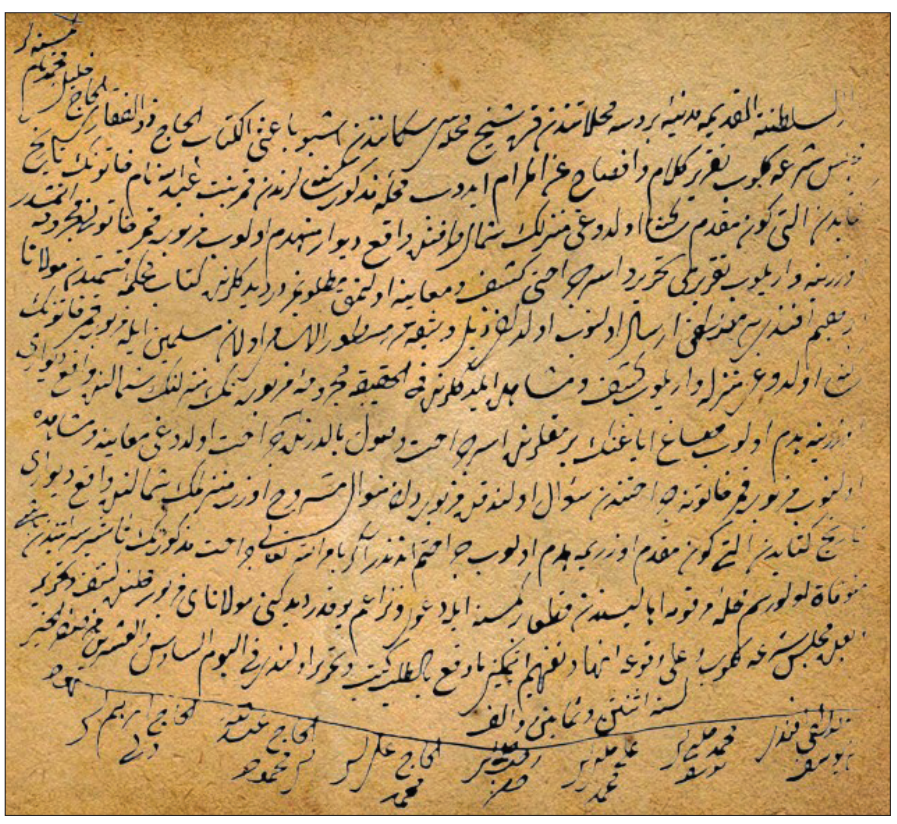

Figure 4 . The document on the investigation and inspection of the woman injured as a result of the fall of the wall of her home, written by the physician, Bursa Shariah records, Bursa of death, how the incident took place, who was involved in the event, and which instruments were used. In the conclusion, the court's exploration report stated its decision according to the testimonies of witnesses and parties. ${ }^{[23,24]}$

\section{Discussion}

Nowadays, doctors partly protect themselves with "informed consent forms" to avoid paying patients for damages arising from medical activities, thus making treatment practices more comfortable. This application, which emerged in the 19th century in the West and referred to as "informed consent," had been applied in Ottoman medical practice for approximately 500 years under the term "riza senedi." The consent notes, which provide important information in terms of medical practice and legal responsibility, protected a physician who encountered an unexpected outcome after treatment, allowing doctors to perform their profession safely. It was also an important official document for the physician to receive the fee, which was determined before treatment, from the patient. ${ }^{[25,26]}$ In terms of patient rights, it ensures that physicians performing the procedure were well-known and competent in their job, and that the surgeon did not exceed intervention limits. Consent certificates, corresponding to today's certificates, and diplomas legitimized doctors' practicing medicine on patients and showed they were competent in their work. ${ }^{[25,27]}$

Despite the consent documents, confirmed in the presence of witnesses, which stated that if the patient were injured or died at the end of the surgery or treatment, the person or the heir would not sue the surgeon, people who were dissatisfied with the result did file lawsuits against physicians in the courts, as shown in the records of Qadi from the period. The processes experienced in the cases of physician errors are similar to those followed today. ${ }^{[11,17]}$ As in a case where the glans penis was injured during the circumcision process, the situation was considered a medical error and, in a similar way to the material compensation of today, the physician paid the patient's parents. ${ }^{[11]}$ In addition, it was

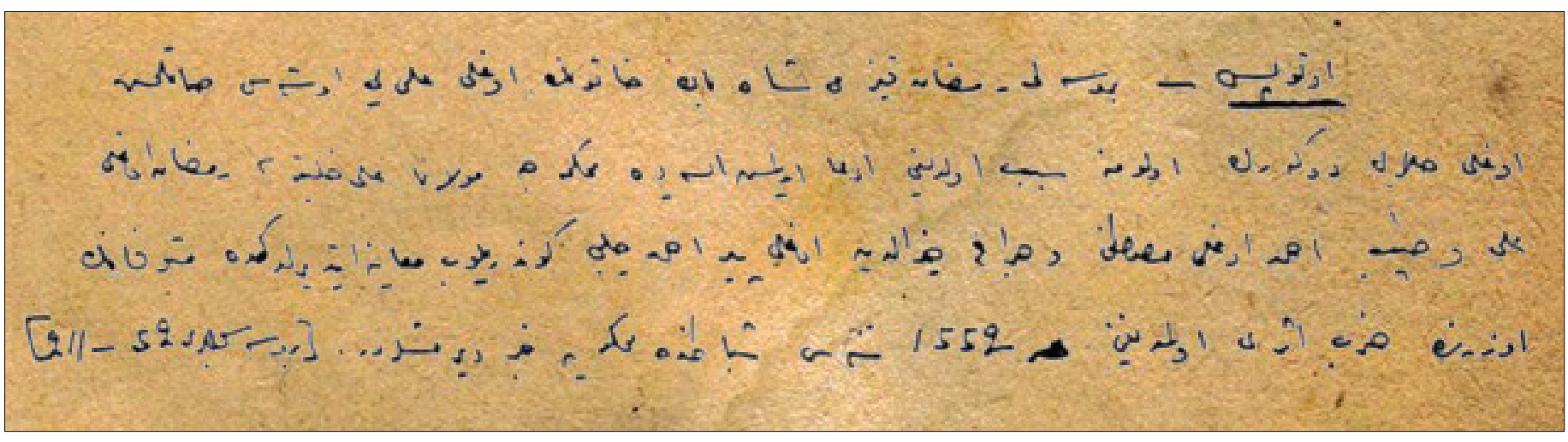

Figure 5. The document on the exploration and examination of a person alleged to be beaten and killed, which was prepared by a physician and surgeon, Bursa Shariah records, Bursa 
observed that the physicians of Dar Al-Shifa and municipality worked in foundations as public physicians for monthly salaries in the Ottoman Empire, while other physicians practiced private medicine, examinations, and initiatives in exchange for payment..$^{[7,11]}$ It is understood that, during the Ottoman period, legal and penal sanctions were imposed on fake doctors or persons without certificates, similar to today. ${ }^{[7,28]}$

The main diseases that people were suffering from and required treatment were also identified from the medical records and, especially, from the consent documents. ${ }^{[29]}$ In the 58 consent documents within the 24 court records from Konya province between the years of 1659-1749, bladder stones and inguinal hernias were reported to be the most common diseases. ${ }^{[27]}$ Bladder stones, inguinal hernias, kidney stones, and tumor surgeries were the most common operations. ${ }^{[28]}$ The emergence of these diseases was caused mainly by the unhealthy environment of the period, severe working conditions, and poor nutrition, although bladder stones and inguinal hernias are still common diseases nowadays.

Again, the most common causes of death during the period were determined by the forensic investigation reports in the court records. $^{[23,24]}$ It was reported that, of the 35 deaths in Kayseri Qadi records between 1650-1660, 63\% were recorded as accidents, $20 \%$ as homicides, and $11 \%$ as illness-associated or spontaneous. ${ }^{[2]}$ In the investigation reports from the Amasya court records of the 17th century, it was reported that mortality was most often due to accidents, followed by murder, illness, spontaneous, and suicidal deaths, respectively, which is similar to the current data. ${ }^{[23]}$ Additionally, in these investigations, there were cases in which the actual causes of death were revealed to be contrary to the alleged or indicated cause; like today, the deception of justice was not allowed. ${ }^{[18,19]}$

Procedures, which required physicians' expertise to ensure safety, body integrity, and health of persons from the beginning of the Ottoman period under the institution of Qadi, became more organized and more inclusive with the "Ceza Kanunname-i Hümayun" which was accepted by the decree of Sultan Abdulmecit (1839-1861) in 1840, which was the first written criminal law. The law clearly explains provisions, such as using physicians' knowledge in cases of beating, injury, rape, and murder, and employing a skilled and competent physician together with the investigating officer for murders. ${ }^{[6]}$

The word autopsy, which is formed by the unification of the words "auto" and "opsis" in Greek, means to see with your own eyes. For the autopsy, which is a scientific examination of the dead body, the words "feth-i ceset," "feth-i meyit and teşrih" were used in the Ottoman Empire. ${ }^{[30]}$ Autopsy practices were introduced in Europe by Dr. Barteloma Da Varignana in 1302 in Bologna, and by Ambroise Pera, the father of autopsy, in 1566 in Paris. However, autopsies were not conducted in the Ottoman Empire until its latter days. ${ }^{[2,6]}$ Although there is a $17^{\text {th }}$ century document stating that Ebubekir Halife, an Ottoman Palace surgeon, gave autopsy lessons called İlm-i Teşrih (autopsy science), the actual conduct of autopsies became possible by the decree that Sultan Abdulmecit signed in 1841 as the Caliph. ${ }^{[6]}$

Examples of medical texts and consent documents in Sharia court records of various cities have provided important information about urogenital diseases and their treatments, applications similar to modern forensic medicine, such as patient-physician relationship, physician's wages, physician's malpractises, and fake physicians, as well as forensic expertise and exploration of the period. The widespread use of informed consent in the Ottoman Empire since the 1500s under the name of consent document ("Riza senedi"), which began to be used in Europe by the 19th century and reached ethical levels only today, showed the advanced level of medical ethics in terms of physician and patient rights in the Ottoman Empire. In spite of the consent document, complaints, and lawsuits against physicians due to the mistakes in medical interventions or treatments, similar to the present day, have also attracted attention.

In cases of suspected death and forensic injury in the Ottoman Empire, the forensic exploration, conducted by a delegation consisting of very reliable persons and a competent physician, and sometimes with Qadi, was an important practice for the manifestation of justice in the conditions of the time.

Ethics Committee Approval: Ethics committee approval was not received for this study from the ethics committee because it was an article about history of urology.

\section{Informed Consent: N/A.}

Peer-review: Externally peer-reviewed.

Conflict of Interest: The author have no conflicts of interest to declare.

Financial Disclosure: The author declared that this study has received no financial support.

\section{References}

1. Sarı N. Osmanlı'larda hekimin eğitimi. Tıp Tarihi Araştırmaları 1988;2:40-64.

2. Bingöl S. The Notes Relating to the Forensic Medicine in the Ottoman Empire According to the Principles of Tanzimat. Tarih Araştırmaları Dergisi 2007;26:37-65. [CrossRef]

3. Eş H. A Glimpse of Forensic Medicine Practices in Ottoman Court Records: Review. Türkiye Klinikleri J Foren Med 2016;13:8-13. [CrossRef] 
4. Koç S, Biçer Ü. Adli Tıbbın Tarihsel Gelişimi, Türkiye'deki Yapılanması ve Sorunları. Klinik Gelişim 2009;22:1-5.

5. Yildirim RV, Ulman YI. A look at the Ottoman social and medical modernization through the life of Dr. Servichen. Bulgarian Historical Review 2013;3:140-50.

6. Gamsız Bilgin N, Ögenler O, Akça T. History of Forensic Autopsy in Türkiye. Lokman Hekim Journal 2011;1:8-12.

7. Yildız B. Non-Muslim doctors and health officials in the Province of Denizli, in the Ottoman era. Pamukkale Tip Dergisi 2014;7:117. [CrossRef]

8. Buharî Ebû Abdullah Muhammed b. İ. Sahîhu'l-buhârî "kitâbü'1ilm”. İstanbul:Çağrı Yayınları, 1981.

9. Demirsoy N. An example of Istanbul sharia court records (Ser'iyye Sicilleri) a start date for Home Care: A document date 1766. Turkish Journal of Family Practice 2017;21:66-73. [CrossRef]

10. Akgündüz A. Osmanlı Devleti'nde Belediye Teşkilâtı ve Belediye Kanunları. İstanbul:Osmanlı Araştırmaları Vakfı, 2005.

11. Çetin O. Bursa Şer’iyye Sicilleri Işı̆̆ında Osmanlılarda İlk Tıp Fakültesi Bursa Darüşşifası ve Tıbbî Faaliyetler. OTAM Dergisi 1993;4:122-50. [CrossRef]

12. Gedikli F. Court Records as a Source for the History of Ottoman Law. Türkiye Araştırmaları Literatür Dergisi 2005;3:187-213.

13. Uzun C. 1638-1639 (H.1048-1049) Dated Harput Shari'ah Register's Presenttation and Index. Firat Üniversitesi Sosyal Bilimler Dergisi 2013;23:255-90.

14. Gündüz T, Kırımlığlu N, Eşiyok B, Demirhan Erdemir A. Informed consent and the legal procedures related to child patient. Turkiye Klinikleri J Med Ethics 2001;9:27-34.

15. Sar1 N. Ethical aspects of Ottoman surgical practice. Turkiye Klinikleri J Med Ethics 2000;8:9-14.

16. Tok Ö. Relations of patient-physician in the ottoman period. Turkish Studies 2008;3:788-805. [CrossRef]

17. Arda B, Aciduman A. Some observations on medicine with the samples from ayıntab sheria court registers. Çocuk Sağlığı ve Hastalıkları Dergisi 2014;57:283-7.
18. Düzbakar Ö. The role of medicine and doctors in judge records during Ottoman period. Turkiye Klinikleri J Med Ethics 2005;13:105-9.

19. Kepecioğlu, K. Bursa Kütüğü, IV. Bursa:Bursa Büyükşehir Belediyesi Yayınları; 2010.

20. Yağmur F, Din H. Evaluation of forensic postmortem examination and autopsies cases performed in Kayseri, 2007. Adli Tip Dergisi 2009;23:18-24.

21. Özen C. Kısa Adlî Tıp Ders Kitabı. İstanbul: İstanbul Üniversitesi Yayınları; 1980.

22. Öztürel A. Adlî Tıp. Ankara: Güzel İstanbul Matbaası; 1971.

23. Kavaklı S. Assessment of Criminal Investigations on Death and Injury Incidents: Examples from the Seventeenth Century Amasya Court Records. History Studies 2013;5:117-42.

24. Tok Ö. Criminal investigations in the judicial records of Kayseri (1650-1660). Sosyal Bilimler Enstitüsü Dergisi 2007;22:32747.

25. Gedikli F. The Medical Liability in the Ottoman Law and the Famous Physician of Hernia of the I $^{\text {th }}$ Century, Türk Hukuk Tarihi Araștırmaları 2007;1:15-27.

26. Kara MA, Aksoy S. On the Ottoman consent documents for medical interventions and the modern concept of informed consent. Saudi Med J 2006;27:1306-10.

27. Demir A. The Sample of Acceptance Form in Konya Ser'iyye Registers (1659-1749). History Studies 2012;4:31-46. [CrossRef]

28. Göktaş H. XIX. Doctor-Patient Relations and Uncertificated Doctors in $19^{\text {th }}$ Century Ottoman Empire. History Studies 2014;6:99115 .

29. Aydın S, Verit A. Informed consent in bladder stone treatment from the Ottoman archives. Schultheiss D, editor. de Historia Urologiae Europaeae Vol.15. Arnhem-The Netherlands: European Association of Urology, Historical Committee; 2008. p.27-35.

30. Maskar Ü. İslam'da ve Osmanlılarda Otopsi sorunu üzerine bir etüd. Patoloji Bülteni, Ankara Patoloji Derneği Yayın Organı 1976;3:259-74. 